\title{
LECTOTYPIFICATION OF PECTIS L. (ASTERACEAE)
}

\section{David J. Keil'}

Linnaeus (1759a) described Pectis and included within it two species, P. ciliaris and P. linifolia. In 1913 Britton and Brown designated P. ciliaris as the lectotype for Pectis. This lectotypification was accepted by the editors of Index Nominum Genericorum (Plantarum) (Farr et al., 1979). I will present evidence below that the lectotypification of Pectis by Britton and Brown was superfluous and that Pectis was actually lectotypified over 90 years earlier by Cassini.

Britton and Brown as adherents of the American Code of Botanical Nomenclature (Anonymous, 1907) followed the mechanical practice of designating "the first binomial species in order" as the lectotype of a genus. This appears to have been the method of lectotypification used for Pectis. This practice is in conflict with the provisions of Article 8 of the International Code of Botanical Nomenclature (Voss et al., 1983).

The choice of Pectis ciliaris as lectotype is also in conflict with the Linnaean protologue of Pectis. Linnaeus (1759a) included both a diagnosis (p. 1221) and a description (p. 1376) for Pectis. The diagnosis is very brief:

PECTIS. Recept. nudum. Pappus aristatus. Cal. 5-phyllus, cylindricus. Flosculi radiantes 5.

Of the features described, the receptacle, the involucre [cal.] and the number of ray florets are the same for both $P$. ciliaris and $P$. linifolia. However, only $P$. linifolia has an aristate pappus. Linnaeus's description of the genus is more thorough than the diagnosis but he again described the pappus of

1 Biological Sciences Department, California Polytechnic State University, San Luis Obispo, CA 93407, U.S.A. 
Pectis only as aristate. The remaining features are applicable equally to both species. The diagnoses of the two species (p. 1221) do not mention the pappus. Later in the same year, however, Linnaeus (1759b) published descriptions for these taxa. He described the achenes and pappus of $P$. ciliaris as follows:

Semina disci coronata setis 5 , basi membranaceis; sem. radii coronata setis 2 .

In contrast the achenes and pappus of $P$. linifolia are described as:

Semina disci aristis 2 ; radii aristis 3 , patulis.

From this it is evident that only the pappus of Pectis linifolia, as interpreted by Linnaeus, is in agreement with the generic protologue.

Each of the two Linnaean species of Pectis is represented in the Linnaean Herbarium by a single herbarium sheet. The aristate nature of the pappus is evident on the type of $P$. linifolia (LINN, cat. no. 1011.2; IDC microfiche 177. 601:III. 4!). On the type of P. ciliaris (LINN, cat. no. 1011.1; IDC microfiche 177. 601:III. 3!) the heads are hidden from view by leaves and the pappus is not visible.

Article 8 states that to be rejected the lectotype must be in serious conflict with the protologue. In view of the present circumscription of Pectis, variation in pappus structure may seem trivial, but this has not always been the case. Largely on the basis of pappus structure, several genera were split away from Pectis in the early 1800's. In the process of describing one of these generic segregates, Chthonia, Cassini (1817) discussed the difference between it and Pectis:

Notre genre Chthonia differe du pectis par l'aigrette, celle des vrais pectis ayant les squamellules subtriquètres, subulées, cornées, parfaitement lisses. Ainsi, les pectis punctata et linifolia doivent demeurer dans le genre Pectis; mais les pectis humifusa, prostrata, et probablement le ciliaris, doivent entre dans le genre Chthonia.

I interpret Cassini's reference to "des vrais pectis" and his accurate description of its pappus as constituting lectotypification of Pectis. According to Article 52, "When a genus is divided into two or more genera, the generic name, if correct, must be retained for one of them." Cassini did not actually make the combination, Chthonia ciliaris. Steudel (1820) validated this combination as a synonym of $P$. ciliaris, attributing it to Cassini. The correct lectotype of Pectis is thus $P$. linifolia and not $P$. ciliaris.

The principal effect of the reinterpretation of the typification of Pectis is on the infrageneric nomenclature. The correct name for the taxon recently revised (Keil, 1978) as sect. Pectidium becomes sect. Pectis. I am currently revising the portion of the genus that contains $P$. ciliaris. The results of that study will determine whether a new name will have to be proposed.

Acknowledgments

Research on Pectis is supported by National Science Foundation Grant DEB 8104683. I thank Dr. John Strother for reviewing the manuscript.

\section{Literature Cited}

Britton, N. L. and A. Brown. 1913. An illustrated flora of the northern United States, Ed. 2. Vol. III. New York.

Cassini, H. 1817. Chthonia. In: G.-F. Cuvier, Dictionnaire des sciences naturelles, 9: 173-174. Paris.

Farr, E. R., J. A. Leussink and F. A. Stafleu (eds.). 1979. Index nominum genericorum (plantarum). Vol. II. Eprolithus-Peersia. Bohn, Scheltema \& Holkema, Utrecht.

Keil, D. J. 1978. Revision of Pectis section Pectidium (Compositae: Tageteae). Rhodora 80: 135146.

Linnaeus, C. 1759a. Systema naturae. Ed. 10. Tomus II: Vegetabilia. Stockholm.

1759b. Plantarum jamaicensium pugillus. Uppsala.

Steudel, E. 1821. Nomenclator botanicus. Stuttgardt.

Voss, E. G. et al. (eds.). 1983. International code of botanical nomenclature. Adopted by the Thirteenth International Botanical Congress. Sydney, August 1981. Bohn, Scheltema \& Holkema, Utrecht/Antwerp. 